\title{
Streptomyces ferralitis sp. nov., a novel streptomycete isolated from a New-Caledonian ultramafic soil
}

\author{
Danielle Saintpierre-Bonaccio, ${ }^{1}$ Hamid Amir, ${ }^{1}$ René Pineau, ${ }^{1}$ \\ Sanaa Lemriss ${ }^{2}$ and Michael Goodfellow ${ }^{3}$ \\ ${ }^{1}$ Laboratoire de Biologie et Physiologie Végetales Appliquées, Université de la \\ Nouvelle-Calédonie, BP4477 98847 Nouméa, New Caledonia \\ ${ }^{2}$ Laboratoire de Mycologie Fundamentale et Appliqueés Biotechnologies Industrielles, Université \\ Claude Bernard-Lyon 1, France \\ ${ }^{3}$ School of Biology, University of Newcastle, Newcastle upon Tyne NE1 7RU, UK
}

\begin{abstract}
The taxonomic position of an actinomycete isolated from an ultramafic soil in New Caledonia was determined using a polyphasic approach. The isolate, which was designated SFOp68 ${ }^{\top}$, was shown to have chemical and morphological properties typical of streptomycetes. An almost complete 16S rRNA gene sequence of the isolate was generated and compared with sequences of representative streptomycetes. The 16S rRNA data not only supported the classification of the strain in the genus Streptomyces, but also showed that it formed a distinct phyletic line that was most closely related to one composed of the type strain of Streptomyces rimosus. The two organisms can be readily separated using a diverse range of phenotypic properties. It is proposed that strain SFOp68 ${ }^{\top}\left(=\mathrm{DSM} 41836^{\top}=\mathrm{NCIMB} 13954^{\top}\right)$ be classified in the genus Streptomyces as Streptomyces ferralitis sp. nov.
\end{abstract}

The genus Streptomyces was proposed by Waksman \& Henrici (1943) and currently contains nearly 600 species with validly published names. The taxon contains aerobic, Gram-positive actinomycetes that form an extensively branched substrate mycelium, produce aerial hyphae that typically differentiate into chains of spores, have LLdiaminopimelic acid but no characteristic sugars in the cell wall (wall chemotype 1 sensu Lechevalier \& Lechevalier, 1970) and possess DNA rich in G + C (Williams et al., 1989; Manfio et al., 1995). It is evident that the genus is underspeciated (Sembiring et al., 2000; Kim \& Goodfellow, 2002) and that the description of Streptomyces species needs to be based on a combination of genotypic and phenotypic data (Manfio et al., 1995, 2003; Atalan et al., 2000; Li et al., 2002). Members of novel streptomycete species are in great demand as a source of novel commercially significant, bioactive compounds (Bérdy, 1995; Dieter et al., 2003).

Actinomycetes dominate bacterial communities in NewCaledonian ultramafic soils (Amir \& Pineau, 1998). These infertile soils, which account for up to a third of the landmass in the country (Jaffré, 1976), have a high level of metal toxicity (due to the presence of high concentrations of chromium, cobalt, iron and nickel) and provide habitats

The GenBank/EMBL/DDBJ accession number for the 16S rRNA gene sequence of Streptomyces ferralitis strain SFOp68 ${ }^{\top}$ is AY262826. for diverse novel actinomycetes that produce bioactive compounds (Saintpierre, 2001; Saintpierre et al., 2003; Saintpierre-Bonaccio et al., 2004). In the course of a screening programme designed to isolate novel bioactive actinomycetes from ultramafic soils, an actinomycete, designated $\mathrm{SFOp} 68^{\mathrm{T}}$, was isolated and provisionally assigned to the genus Streptomyces. The aim of the present study was to determine the taxonomic status of the strain using genotypic and phenotypic procedures. The resultant data indicate that the organism should be classified as a novel species of Streptomyces, for which the name Streptomyces ferralitis sp. nov. is proposed.

Strain SFOp68 ${ }^{\mathrm{T}}$ was isolated from a $10^{-1}$ suspension of a ferralitic, oxidic, ultramafic soil that had been heat-pretreated at $100{ }^{\circ} \mathrm{C}$ for $15 \mathrm{~min}$ and then used to inoculate a chitin/vitamin B agar plate (Hayakawa \& Nonomura, 1987) supplemented with cycloheximide $\left(100 \mu \mathrm{g} \mathrm{ml}^{-1}\right)$ and polymyxin $\left(25 \mu \mathrm{g} \mathrm{ml}^{-1}\right)$ and incubated at $30{ }^{\circ} \mathrm{C}$ for 2 weeks. The soil sample had been collected from the 'Ouenarou' region in the southern part of the main island of New Caledonia [see Institut National Geographique map no. 4835 (Yaté), série orange, $7549 \cdot 5 \times 681 \cdot 5]$. The isolate was tested for purity, maintained on modified Bennett's agar (MBA; Jones, 1949) and preserved as a mixture of hyphae and spores in $20 \%(\mathrm{v} / \mathrm{v})$ glycerol at $-20{ }^{\circ} \mathrm{C}$. 
The isolate was grown on MBA (Jones, 1949) and peptone/ yeast extract/iron agar [ISP 6 (Difco); Shirling \& Gottlieb, 1966] plates at $30^{\circ} \mathrm{C}$ for 14 days. The colour of the aerial spore mass, the pigmentation of the substrate mycelium and the colour of any diffusible pigment on MBA were recorded, as well as the ability to form melanin pigments on ISP 6 agar. Spore-chain morphology and spore ornamentation were observed by using a Cambridge Stereoscan 240 scanning electron microscope to study a culture grown on oatmeal agar [ISP 3 (Difco); Shirling \& Gottlieb, 1966] for 3 weeks at $30^{\circ} \mathrm{C}$ by following the procedure described by O’Donnell et al. (1993).

Most of the phenotypic tests were carried out using the media and methods described by Williams et al. (1983). The ability of the test strain to grow in MBA supplemented with erythromycin $\left(4 \mu \mathrm{g} \mathrm{ml}^{-1}\right)$, gentamicin sulphate $(10 \mu \mathrm{g}$ $\left.\mathrm{ml}^{-1}\right)$, penicillin $\left(25 \mu \mathrm{g} \mathrm{ml}^{-1}\right)$, rifampicin $\left(6 \mu \mathrm{g} \mathrm{ml}^{-1}\right)$, streptomycin sulphate $\left(5 \mu \mathrm{g} \mathrm{ml}^{-1}\right)$, tetracycline hydrochloride $\left(30 \mu \mathrm{g} \mathrm{ml}^{-1}\right)$ and vancomycin hydrochloride $\left(10 \mu \mathrm{g} \mathrm{ml}^{-1}\right)$ was examined following incubation of plates at $30^{\circ} \mathrm{C}$ for 7 days. Similarly, the organism was examined for its ability to grow in MBA supplemented with crystal violet $(0.0002 \%, \mathrm{w} / \mathrm{v})$, phenol $(0.01 \%, \mathrm{w} / \mathrm{v})$, potassium tellurite $(0.005 \%, w / v)$ and sodium chloride $(5 \%, w / v)$. Lipase activity was detected using Sierra's medium (Sierra, 1957) supplemented with Tween $80(1 \%, \mathrm{v} / \mathrm{v})$. Standard procedures were used to determine the isomeric form of LL-diaminopimelic acid and any major whole-organism sugars (Staneck \& Roberts, 1974). A standard procedure was also used to detect the predominant isoprenoid quinone (Minnikin et al., 1984). The antimicrobial activity of the test strain was determined against a range of bacteria and fungi, as described by Saintpierre et al. (2003).

Extraction of genomic DNA and PCR amplification and sequencing of a $16 \mathrm{~S}$ rRNA gene from strain SFOp68 ${ }^{\mathrm{T}}$ was achieved using previously described procedures (Kim et al., 1999). The resultant rRNA gene sequence was aligned manually using the PHYDIT program (Chun, 1995) against corresponding sequences of members of the family Streptomycetaceae (Kim et al., 2003) retrieved from the DDBJ, EMBL and GenBank databases. Unrooted phylogenetic trees were inferred using the least-squares (Fitch \& Margoliash, 1967), maximum-likelihood (Felsenstein, 1993) and neighbour-joining (Saitou \& Nei, 1987) tree-making algorithms from the PHYLIP suite of programs (Felsenstein, 1993). Evolutionary distance matrices for the least-squares and neighbour-joining methods were generated as described by Jukes \& Cantor (1969). Tree topologies were evaluated by a bootstrap analysis of the neighbour-joining dataset, based on 1000 resamplings, using the SEQBOOT and CONSENSE programs from the PHYLIP package. A partial nucleotide sequence $(120 \mathrm{nt})$ of the tested strain based on the variable $\gamma$-region was compared with corresponding nucleotide sequences of Streptomyces strains retrieved from GenBank. A phylogenetic tree based on these sequences was generated using the neighbour-joining algorithm.
The chemical and morphological properties of isolate SFOp $68^{\mathrm{T}}$ are consistent with its classification in the genus Streptomyces (Williams et al., 1989; Manfio et al., 1995). The organism forms an extensively branched substrate mycelium, aerial hyphae that differentiate into chains of spores, contains LL-diaminopimelic acid in the wall peptidoglycan, lacks characteristic major sugars and has octahydrogenated menaquinones with nine isoprene units as the predominant isoprenologue. The assignment of the strain to the genus Streptomyces is also supported by the results of the $16 \mathrm{~S}$ rRNA gene sequence studies.

Comparison of the almost complete 16S rRNA nucleotide gene sequence of strain SFOp68 ${ }^{\mathrm{T}}$ (1490 nt) with corresponding streptomycete sequences clearly shows that the organism forms a distinct phyletic line in the Streptomyces $16 \mathrm{~S}$ rRNA gene tree irrespective of the tree-making algorithm used (Fig. 1). The isolate was most closely related to the type strain of Streptomyces rimosus: the two strains shared a $16 \mathrm{~S}$ rRNA gene sequence similarity of $97 \cdot 9 \%$, a value which corresponds to $31 \mathrm{nt}$ differences at 1434 sites. The organism also shared relatively high 16S rRNA gene sequence similarity values with the other organisms shown in Fig. 1, notably with the type strains of Streptomyces violaceusniger (97·8\%), Streptomyces yogyakartensis (97.7\%), Streptomyces javensis $(97 \cdot 5 \%)$, Streptomyces albofaciens $(97 \cdot 4 \%)$, Streptomyces auranticolor $(97 \cdot 4 \%)$, Streptomyces cangkringensis $(97 \cdot 4 \%)$, Streptomyces griseiniger $(97 \cdot 4 \%)$, Streptomyces hygroscopicus $(97 \cdot 4 \%)$ and Streptomyces phaeoluteogriseus $(97 \cdot 4 \%)$. DNA-DNA relatedness studies were not carried out between strain $\mathrm{SFOp} 68^{\mathrm{T}}$ and any of these organisms, as representatives of other pairs of Streptomyces species with similarly low rRNA gene sequence similarities (Sembiring et al., 2000; Kim \& Goodfellow, 2002; Manfio et al., 2003) show relatedness values below the $80 \%$ cut-off point recommended for the recognition of genomic species of Streptomyces (Labeda \& Lyons, 1992; Labeda, 1993, 1998). The sharp separation of strain SFOp $68^{\mathrm{T}}$ from representatives of Streptomyces species with validly published names was underpinned by the results from the $120 \mathrm{nt}$ sequence analysis (data not shown) as, once again, the organism was found to be most closely related to the type strain of Streptomyces rimosus.

Strain SFOp $68^{\mathrm{T}}$ forms smooth, ornamented spores in loops and spirals (Fig. 2) and does not produce melanin pigments on peptone/yeast extract/iron agar; these properties are also shown by Streptomyces rimosus ISP $5260^{\mathrm{T}}$ (Shirling \& Gottlieb, 1968). However, the two organisms have markedly different phenotypic profiles: only the Streptomyces rimosus strain degrades elastin, uses adonitol, $\mathrm{L}(+)$ arabinose, $\mathrm{D}(+)$-cellobiose, $\mathrm{D}(+)$-lactose, $\mathrm{D}(+)$-melibiose and sodium citrate as sole carbon sources and grows in the presence of $5 \%(\mathrm{w} / \mathrm{v})$ sodium chloride (Williams et al., 1983). However, isolate SFOp $68^{\mathrm{T}}$, unlike the Streptomyces rimosus strain, grows at $45^{\circ} \mathrm{C}$.

It is evident that isolate $\mathrm{SFOp} 68^{\mathrm{T}}$ can be distinguished from Streptomyces species with validly published names, 


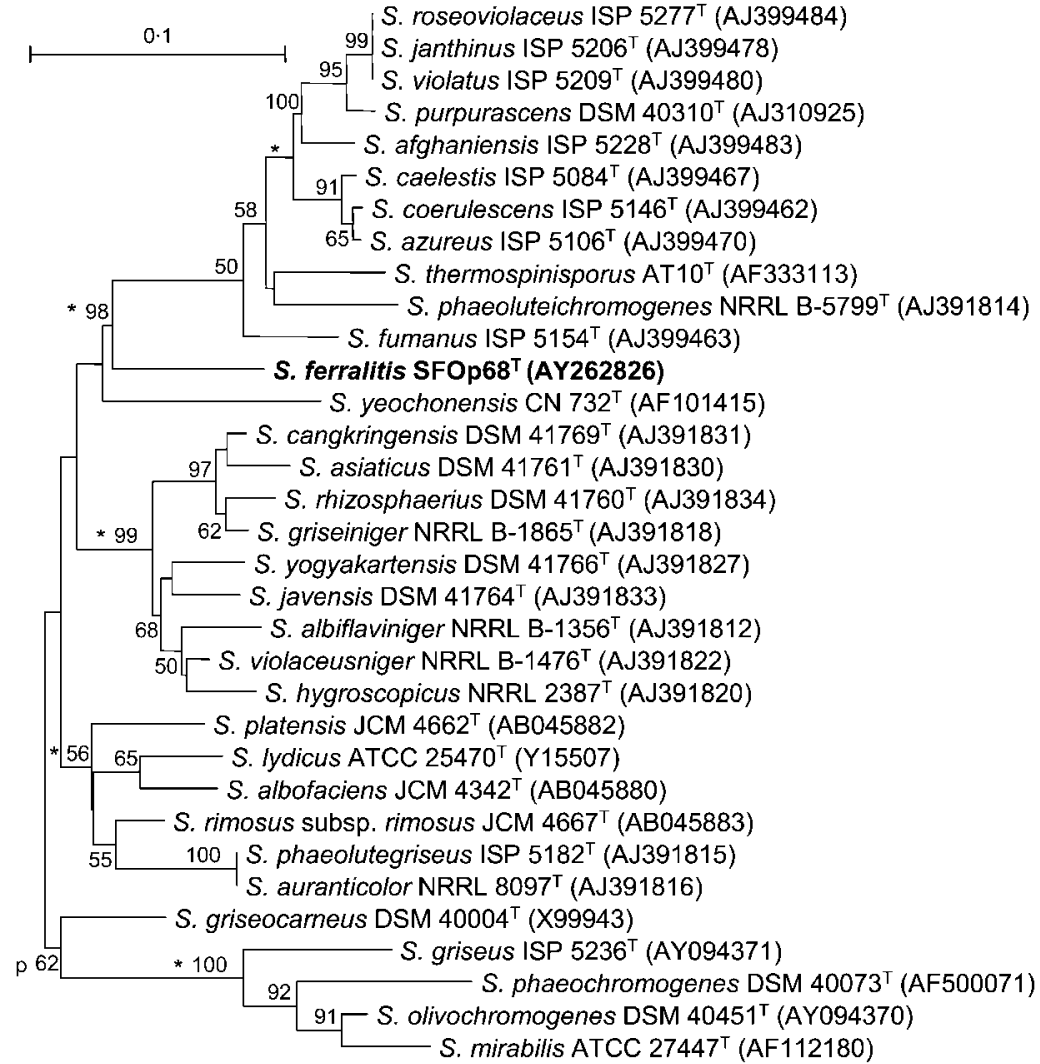

Fig. 1. Neighbour-joining tree (Saitou \& Nei, 1987), based on nearly complete $16 \mathrm{~S}$ rRNA gene sequences, showing the position of strain SFOp68 ${ }^{\top}$ in the streptomycete tree. Asterisks indicate branches that were also recovered using the least-squares (Fitch \& Margoliash, 1967), maximum-likelihood (Felsenstein, 1993) and maximum-parsimony (Kluge \& Farris, 1969) tree-making algorithms; $p$ indicates a branch formed using the maximum-parsimony treeing method. Numbers at nodes are percentage bootstrap values based on 1000 resampled datasets; only values above $50 \%$ are given. Bar, $0 \cdot 1$ nucleotide substitutions per nucleotide position. notably Streptomyces rimosus, using a combination of genotypic and phenotypic properties. It is proposed, therefore, that this organism be given species status in the genus Streptomyces as Streptomyces ferralitis sp. nov.

\section{Description of Streptomyces ferralitis sp. nov.}

Streptomyces ferralitis (fer.ra'li.tis. N.L. gen. n. ferralitis of ferralite, denoting the type of soil from which the type strain was isolated).

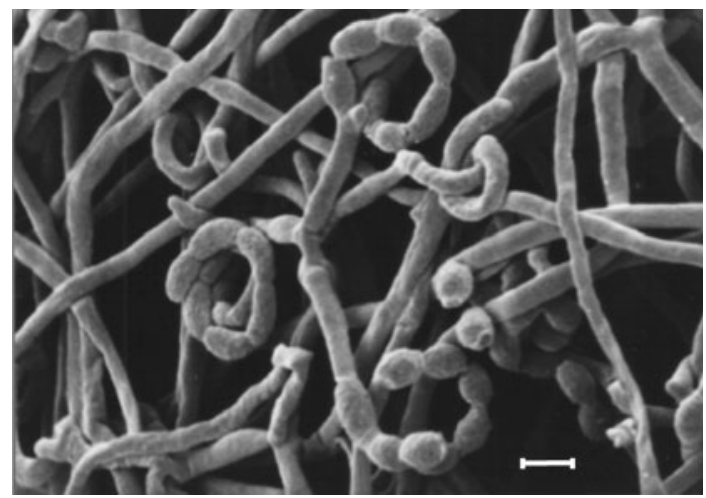

Fig. 2. Scanning electron micrograph of strain SFOp68 ${ }^{\top}$ showing looped to spiral chains of smooth-surfaced spores after 3 weeks growth at $30^{\circ} \mathrm{C}$ on oatmeal agar. Bar, $1 \mu \mathrm{m}$.
Aerobic, Gram-positive actinomycete that forms an extensively branched substrate mycelium and aerial hyphae that differentiate into looped or spiral chains of spores. The spore chains consist of up to 15 barrel-shaped spores with smooth surfaces. A brown substrate mycelium and a white aerial spore mass are formed on MBA. Melanin pigments are not produced on peptone/yeast extract/iron agar. The culture grows well at 20 and $45^{\circ} \mathrm{C}$, but does not grow at $10^{\circ} \mathrm{C}$. Metabolizes casein, hypoxanthine, L-tyrosine, urea and xanthine, but not adenine, elastin, gelatin, guanine, starch, Tween 80 or xanthine. $\mathrm{D}(+)$-Galactose, $\mathrm{D}(+)$ glucose, $\mathrm{D}(+)$-mannitol, $\mathrm{D}(+)$-mannose and $\mathrm{D}(+)$-trehalose are used as sole carbon sources for energy and growth, but adonitol, D-arabinose, $\mathrm{D}(+)$-cellobiose, $\mathrm{D}(+)$-melibiose and sodium citrate are not. The organism is resistant to penicillin $\left(25 \mu \mathrm{g} \mathrm{ml}^{-1}\right)$, but does not grow in the presence of erythromycin $\left(4 \mu \mathrm{g} \mathrm{ml}{ }^{-1}\right)$, gentamicin sulphate $(10 \mu \mathrm{g}$ $\left.\mathrm{ml}^{-1}\right)$, rifampicin $\left(6 \mu \mathrm{g} \mathrm{ml}^{-1}\right)$, streptomycin sulphate $\left(5 \mu \mathrm{g} \mathrm{ml}^{-1}\right)$, tetracycline hydrochloride $\left(30 \mu \mathrm{g} \mathrm{ml}^{-1}\right)$, vancomycin hydrochloride $\left(10 \mu \mathrm{g} \mathrm{ml}^{-1}\right)$, crystal violet $(0.0002 \%, \mathrm{w} / \mathrm{v})$, phenol $(0.01 \%, \mathrm{w} / \mathrm{v})$, potassium tellurite $(0.005 \%, \mathrm{w} / \mathrm{v})$ or sodium chloride $(5 \%, \mathrm{w} / \mathrm{v})$. It shows activity against clinical isolates of Candida albicans, Staphylococcus aureus, Staphylococcus epidermidis and a Corynebacterium strain, but not against Fusarium oxysporum, Bacillus, Erwinia, Escherichia coli, Klebsiella pneumoniae or Pseudomonas aeruginosa strains.

The type strain, SFOp68 $8^{\mathrm{T}} \quad\left(=\mathrm{DSM} \quad 41836^{\mathrm{T}}=\mathrm{NCIMB}\right.$ 
$13954^{\mathrm{T}}$ ), was isolated from a ferralitic, oxidic ultramafic soil collected at the southern end of the main island of New Caledonia. The species description is based upon a single strain and hence serves as the description of the type strain.

\section{Acknowledgements}

The authors are indebted to Dr Pierre Cabalion (IRD, Institut pour la Recherche et le Development, Nouméa, New Caledonia) for the provision of organisms for the antimicrobial activity studies from the Institut Pasteur of Nouméa, to Carlos Rodriguez (University of Newcastle upon Tyne, UK) for carrying out the phylogenetic analyses and to Professor Jean Euzéby (Ecole Nationale Vétérinaire, Toulouse, France) for help with the naming of the species. H. A., R.P. and D.S. are indebted to la Direction des Ressources Naturelles (DRN) de la Province Sud de la Nouvelle-Calédonie for financing the project.

\section{References}

Amir, H. \& Pineau, R. (1998). Influence of plants and cropping on microbiological characteristics of some New Caledonian ultramafic soils. Aust J Soil Res 361, 457-471.

Atalan, E., Manfio, G. P., Ward, A. C., Kroppenstedt, R. M. \& Goodfellow, M. (2000). Biosystematic studies on novel streptomycetes from soil. Antonie van Leeuwenhoek 77, 337-353.

Bérdy, J. (1995). Are actinomycetes exhausted as a source of secondary metabolites? Biotechnologia 7-8, 13-34.

Chun, J. (1995). Computer-assisted classification and identification of actinomycetes. $\mathrm{PhD}$ thesis, University of Newcastle, UK.

Dieter, A., Hamm, A., Fiedler, H.-P., Goodfellow, M., Müller, W. E. G., Brun, R., Beil, W. \& Bringmann, G. (2003). Pyrocoll, an antibiotic, antiparasitic and antitumor compound produced by a novel alkalophilic Streptomyces strain. J Antibiot 56, 639-646.

Felsenstein, J. (1993). PHYLIP (Phylogenetic Inference Package), version 3.5c. Distributed by the author. Department of Genetics, University of Washington, Seattle, USA.

Fitch, W. M. \& Margoliash, E. (1967). Construction of phylogenetic trees: a method based on mutation distances as estimated from cytochrome $c$ sequences is of general applicability. Science 155, 279-284.

Hayakawa, M. \& Nonomura, H. (1987). Humic acid-vitamin agar, a new medium for the selective isolation of soil actinomycetes. J Ferment Technol 65, 501-509.

Jaffrè, T. (1976). Chemical composition and conditions of mineral supply for plants on ultrabasic rocks. In ORSTOM Notebook, Biology Series II, pp. 53-63. Paris: ORSTROM (in French).

Jones, K. L. (1949). Fresh isolates of actinomycetes in which the presence of sporogeneous aerial mycelia is a fluctuating characteristic. J Bacteriol 57, 141-145.

Jukes, T. H. \& Cantor, C. R. (1969). Evolution of protein molecules. In Mammalian Protein Metabolism, vol. 3, pp. 21-132. Edited by H. N. Munro. New York: Academic Press.

Kim, S. B. \& Goodfellow, M. (2002). Streptomyces thermospinisporus sp. nov., a moderately thermophilic carboxydotrophic streptomycete isolated from soil. Int J Syst Evol Microbiol 52, 1225-1228.

Kim, S. B., Brown, R., Oldfield, C., Gilbert, S. C. \& Goodfellow, M. (1999). Gordonia desulfuricans sp. nov., a benzothiophenedesulphurizing actinomycete. Int J Syst Bacteriol 49, 1845-1851.

Kim, S. B., Lonsdale, J., Seong, C.-N. \& Goodfellow, M. (2003). Streptacidiphilus gen. nov., acidophilic actinomycetes with wall chemotype I and emendation of the family Streptomycetaceae
(Waksman and Henrici $(1943)^{\mathrm{AL}}$ ) emend. Rainey et al. 1997. Antonie van Leeuwenhoek 83, 107-116.

Kluge, A. G. \& Farris, F. S. (1969). Quantitative phyletics and the evolution of anurans. Syst Zool 18, 1-32.

Labeda, D. P. (1993). DNA relatedness among strains of the Streptomyces lavendulae phenotypic cluster group. Int J Syst Bacteriol 43, 822-825.

Labeda, D. P. (1998). DNA relatedness among the Streptomyces fulvissimus and Streptomyces griseoviridis phenotypic cluster groups. Int J Syst Bacteriol 48, 829-832.

Labeda, D. P. \& Lyons, A. J. (1992). DNA relatedness among strains of the sweet potato pathogen Streptomyces ipomoea (Person and Martin 1940) Waksman and Henrici 1948. Appl Environ Microbiol 58, 532-535.

Lechevalier, M. P. \& Lechevalier, H. (1970). Chemical composition as a criterion in the classification of aerobic actinomycetes. Int J Syst Evol Microbiol 20, 435-443.

Li, W., Lanoot, B., Zhang, Y., Vancanneyt, M., Swings, J. \& Liu, Z. (2002). Streptomyces scopiformis sp. nov., a novel streptomycete with fastigiate spore chains. Int J Syst Evol Microbiol 52, 1629-1633.

Manfio, G. P., Zakrzewska-Czerwinska, J., Atalan, E. \& Goodfellow, M. (1995). Towards minimal standards for the description of Streptomyces species. Biotechnologia 7-8, 242-253.

Manfio, G. P., Atalan, E., Zakrzewska-Czerwinska, J., Mordarski, M., Rodriguez, C., Collins, M. D. \& Goodfellow, M. (2003). Classification of novel soil streptomycetes as Streptomyces aureus sp. nov., Streptomyces laceyi sp. nov. and Streptomyces sanglieri sp. nov. Antonie van Leeuwenhoek 83, 245-255.

Minnikin, D. E., O'Donnell, A. G., Goodfellow, M., Alderson, G., Athalye, M., Schaal, A. \& Parlett, J. H. (1984). An integrated procedure for the extraction of bacterial isoprenoid quinones and polar lipids. J Microbiol Methods 2, 233-241.

O'Donnell, A. G., Falconer, C., Goodfellow, M., Ward, A. C. \& Williams, E. (1993). Biosystematics and diversity amongst novel carboxydotrophic actinomycetes. Antonie van Leeuwenhoek 64, 325-340.

Saintpierre, D. (2001). Identification of novel actinomycete strains from New-Caledonian ultramafic soils. Chemical characterization of some antibiotic products. $\mathrm{PhD}$ thesis, Institut National Polytechnique de Toulouse, France (in French).

Saintpierre, D., Amir, H., Pineau, R., Sembiring, L. \& Goodfellow, M. (2003). Streptomyces yatensis sp. nov., a novel bioactive streptomycete isolated from a New-Caledonian ultramafic soil. Antonie van Leeuwenhoek 83, 21-26.

Saintpierre-Bonaccio, D., Maldonado, L. A., Amir, H., Pineau, R. \& Goodfellow, M. (2004). Nocardia neocaledoniensis sp. nov., a novel actinomycete isolated from a New-Caledonian brown hypermagnesian soil. Int J Syst Evol Microbiol 54, 599-603.

Saitou, N. \& Nei, M. (1987). The neighbor-joining method: a new method for reconstructing phylogenetic trees. Mol Biol Evol 4, 406-425.

Sembiring, L., Ward, A. C. \& Goodfellow, M. (2000). Selective isolation and characterisation of members of the Streptomyces violaceusniger clade associated with roots of Paraserianthes falcataria. Antonie van Leeuwenhoek 78, 353-366.

Shirling, E. B. \& Gottlieb, D. (1966). Methods for characterization of Streptomyces species. Int J Syst Bacteriol 16, 313-340.

Shirling, E. B. \& Gottlieb, D. (1968). Cooperative description of the type strains of Streptomyces. III. Additional species descriptions from the first and second studies. Int J Syst Bacteriol 18, 279-392.

Sierra, G. (1957). A simple method for detection of lipolytic activity of microorganisms and some observations on the influence of the 
contact between cells and fatty substrates. Antonie van Leeuwenhoek 23, 15-22.

Staneck, J. L. \& Roberts, G. D. (1974). Simplified approach to the identification of aerobic actinomycetes by thin-layer chromatography. Appl Microbiol 28, 226-231.

Waksman, S. A. \& Henrici, A. T. (1943). The nomenclature and classification of the actinomycetes. J Bacteriol 46, 337-341.
Williams, S. T., Goodfellow, M., Alderson, G., Wellington, E. M. H., Sneath, P. H. A. \& Sackin, M. J. (1983). Numerical classification of Streptomyces and related genera. J Gen Microbiol 129, 1742-1813.

Williams, S. T., Goodfellow, M. \& Alderson, G. (1989). Genus Streptomyces Waksman and Henrici 1943, 339 ${ }^{\mathrm{AL}}$. In Bergey's Manual of Systematic Bacteriology, vol. 4, pp. 2452-2492. Edited by S. T. Williams, M. E. Sharpe \& J. G. Holt. Baltimore: Williams \& Wilkins. 